application for suspension be made in good faith. ${ }^{33}$ Suspension should not be denied on the basis of political beliefs that do not in themselves justify deportation. To assure that these standards are followed, the Immigration Service should be required to hold a full hearing, not only on the question of whether the alien technically qualifies for suspension, ${ }^{34}$ but also on the question of whether suspension should be granted. At that hearing, the alien should be given opportunity to rebut all evidence and charges introduced against him on both points. ${ }^{35}$ The Attorney-General's decision should then be based solely on the record made at the hearing. ${ }^{36}$ These steps would enable a reviewing court to examine the record for evidence to support the decision and to determine whether the decision conforms to the prescribed standards of guidance. In this way, the harshness springing from the Attorney-General's broad discretion can be eliminated.

\title{
STATE SUPERVISION OVER INSURANCE RATE-MAKING COMBINATIONS UNDER THE MCCARRAN ACT*
}

INSURANCE rates are calculated on the assumption that future losses will reflect past experience. Promulgation of accurate rates depends there-

33. Conceivably, an alien, knowing of the provisions of the law, might illegally enter the country and deliberately establish his eligibility for suspension as part of a preconceived plan to gain permanent residence in the United States by means of this procedure. Since the law provides that all suspended deportation orders be counted against the immigration quota of the alien's country of nationality, 54 STAT. 671 (1940), 8 U.S.C. $\$ 155 \mathrm{c}$ (1946), the interest of fairness to other prospective immigrants from that country demands that only bona fide claimants to suspension of deportation be given favorable consideration.

34. Of course, the regulations of the Immigration Service already assure the alien a full hearing on all issues relating to his eligibility for suspension. See note 18 supra.

35. Although there was no opportunity to rebut the basis of the Attorney-General's decision in the Kaloudis case, this has always been regarded as basic to due process of law. See, Interstate Commerce Commission v. Louisville \& Nashville Ry., 227 U.S. 88, 93 (1913). For an application of this principle to discretionary relief proceedings, see U.S. ex rel. Salvetti v. Reimer, 103 F.2d 777, 779 (2d Cir. 1939).

36. This has always been regarded as a fundamental attribute of a fair hearing. See, Whitfield v. Hanges, 222 Fed. 745, 749 (8th Cir. 1915); Kwock Jan Fat v. White, 253 U.S. 454 (1920). This requirement was adopted by the Immigration Service in suspension proceedings as a result of the case of Matter of Alexiou, A-6178382, Bd. of Imm. App. Nov. 8, 1949, cited in Brief for Relator, p. 33. The Board held that "while the grant or denial of suspension of deportation is discretionary, the exercise of this discretion must be based upon the evidence of record." This position was approved by the Attorney-General, although he later reversed himself without explanation. Brief for Respondent, p. 11. For a further illustration of the principle that the decision must be based on evidence in record see U.S. $e x \mathrm{rel}$. Bauer v. Shaughnessy, Civ. 50-217 (S.D. N.Y. 1949). Contra, U.S. ex rel. Von Kleczkowski v. Watkins, 71 F. Supp. 429 (S.D. N.Y. 1947) (Attorney-General permitted to rely on "top secret" military report in denying discretionary relief).

* North Little Rock Transportation Co. v. Casualty Reciprocal Exchange, 181 F.2d 174 (Sth Cir 1950), cert. denied, 19 U.S.L. WEeK 3087 (U.S. Oct. 10, 1950). 
fore on the use of comprehensive loss data. But few companies do enough business in all lines of insurance to amass a statistical base broad enough for reliable prediction of all types of losses. As a result, individual companies have found it necessary to pool their loss experience. ${ }^{1}$ And since the cost of maintaining separate rating systems is prohibitive, ${ }^{2}$ insurers have gone beyond the joint compiling of statistics to engage in joint rate making. ${ }^{3}$

However compelling the business reasons for permitting collaboration in the setting of insurance rates, ${ }^{4}$ that practice fell directly under the price-fixing interdiction of the Sherman Act ${ }^{5}$ when in 1944 insurance was judicially

1. See KNIGHT, Risk, UnCERTAINTy AND Profit 245-52 (1921); Gorman, State Regulation and Public Law 15. ProceEdings of the Section of INSURANCE Law, AMerican Bar Association 301, 303 (1946); Gardner, Insurance and the Anti-Trust Laws, $61 \mathrm{H}$ aRv. L. REv. 246, 258 (1948); Note, The Regulation of Insurance Rates, 47 Cor. L. REv. 1314, $1317-18$ (1947).

2. In some insurance fields, for example, in workmen's compensation, the rate structure is so complicated that it is impractical, if not impossible, for a company to make its own rates. In such fields, if a company is to survive, it must belong to a rating bureau. The operation of the bureau is so expensive that there is little likelihood of competing bureaus performing the same function. For an example, see State v. American Insurance Co., 355 Mo. 1053, 200 S.W.2d 1, 9 (1947). On the other extreme lie some rating fields in which companies can readily make their own rates. But even here, companies find it expendient to combine their rate making functions in order to simplify one phase of their operations and reduce one large item of overhead expense. See N. Y. Insurance Superintendent Dineen, The Rating Problem, Proceedings of the Section of Insurance Law, Asierican Bar Association 104, 113 (1945).

3. An additional reason for permitting collaboration is that free and unregulated competition in insurance, which has had a fair trial in this country under many old state anticombination statutes, has proved spectacularly unsuccessful. Rate wars resulted in the destruction of small companies and the demoralization of the industry. See Maryott, $W h y$ Regulate Insurance Rates, ProceEdings of the Section of INSURAnce LAw, AMrerican Bar Association 305, 310-11 (1946). And of. Osborn v. Ozlin, 310 U.S. 53, 65 (1940): "Government has always had a special relation to insurance. The ways of safeguarding against the untoward manifestations of nature and other vicissitudes of life have long been withdrawn from the benefits and caprices of free competition."

People unpersuaded of the tremendous cost of rating might suggest that the advantages flowing from the free interchange of loss data may be achieved without sanctioning the further step of joint rate making. But at least one eminent authority feels that no practical line can be drawn between joint compilation and joint rate setting, and that a state must choose squarely between prohibiting or permitting (and regulating) collaboration. PATTERSON, THE INSURANCE COMMISSIONER IN THE UNITED States 273 (1927).

4. The additional reason has been advanced that the assurance of solvency-a primary purpose of regulation-can best be achieved by eliminating competition and permitting insurers to cushion rates by joint action. This view is indicated, though not necessarily espoused, by Gardner, Insurance and the Anti-Trust Laves, 61 HARv. L. REv. 246, 272 (1948). Former Assistant Attorney General Berge insists, on the other hand, that state regulation guards against insolvency by compelling insurers to maintain reserves and restricting the range of their investments. He also asserts that underwriting judgment and executive management are more important to the preservation of financial stability than agreement on rates. Berge, Insurance and the Anti-trust Laws, Proceedings of THE SEction of Insurance Law, American Bar Association 29, 33 (1946).

5. 26 STAT. 209 (1890), 15 U.S.C. $\S 1-7$ (1946). The principle is now firmly estab- 
declared interstate commerce. ${ }^{6}$ As the peculiarities of the insurance business render insistence on separate action by each insurer neither feasible nor desirable, Congress was urgently solicited to exempt joint rate making in this field from the applicability of the antitrust laws.

But Congress was not prepared to acquiesce in completely uncontrolled private rate-making. Anxiety was expressed that a non-competitive industry, if unregulated, might ensconce incompetent management and underwriting by maintaining an artificially high rate structure. ${ }^{7}$

Some governmental surveillance being clearly indicated, Congress was faced with the alternative of devising a federal supervisory scheme or authorizing control by the states. The decision in favor of the latter reflected the fear that chaos would accompany the disruption of well-rooted state regulation and taxation of insurance companies. ${ }^{8}$ Thus, the McCarran

lished that price fixing combinations in interstate commerce are illegal per se under the Sherman Act regardless of the reasonableness of the restraint. United States v. Trenton Potteries Co., 273 U.S. 392 (1927); United States v. Socony-Vacuum Oil Co., 310 U.S. 150 (1940).

6. In United States v. South-Eastern Underwriters Association, 322 U.S. 533 (1944), the Supreme Court upheld an indictment charging the member companies of the SouthEastern Underwriters Association with conspiring to restrain trade in interstate commerce by combining to set insurance rates. The effect of the decision was to reverse the seventyfive year old rule of Paul v. Virginia, 75 U.S. 168 (1868), that the writing of a policy of insurance was not a transaction in commerce.

The South-Eastern Underwriters case has been extensively commented on. See, e.g., Berke, Is the Business of Insurance Commerce? 42 MICH. L. REv. 409 (1943); Powell, Insurance as Commerce, 57 HaRv. L. REv. 937 (1944); Notes, 32 GEo. L. REv. 66 (1943); 29 Marq. L. Rev. 55 (1944); 45 Col. L. Rev. 927 (1945); 20 Ind. L. Rev. 184 (1947). See also, Timberg, Insturance and Interstate Commerce, 50 YALE L.J. 959 (1941) which preceded and predicted the decision.

7. Joint Hearings, Subcommittee of Committee on the Judiciary on S. 1362, H.R. 3269, and H.R. 3270, 78th Cong., 1st Sess., Parts 1-4, 55-57, 142 (1943). This fear was well substantiated by the conditions prevailing prior to the South-Eastern Underwriters decision. Thus a Department of Justice survey concluded that about one half of the states in which rating bureaus operated made inadequate provision for regulation and left the public virtually at the mercy of insurance companies. See Orfield, Improving State Regulation of Insurance, 32 MINN. L. REv. 219, 233 (1948). A survey undertaken by a legal commentator arrived at the same conclusion. See Note, Instrance, A Survey of State Rate Regulation, 33 GEo. L.J. 70, 90-1 (1914). Such information prompted Congress to reject the Walter-BaileyVan Nuys Bill, S. 1362, H.R. 3269, H.R. 3270, 78 th Cong., 1st Sess. (1943), introduced before the Supreme Court handed down the South-Eastern Underwriters case, which purported to exempt the insurance business entirely from the federal antitrust laws.

8. See Sen. Rep. No. 20, 79th Cong., 1st Sess. (1945).

For an additional reason underlying the congressional preference for state control, see Professor Patterson: "An insurance company which [under the present system of state control wants] to do a countrywide business [is] compelled, in order to obtain a license to do business in the more populous states, to conform its investments and many other practices to the highest standard set by any of these states. I doubt if Congressional legislation, emerging from the mill of countless local pressure groups, would set as high standards for countrywide operation." Patterson, The Future of State Supervision of Insurance, 23 TEx. L. REv. 18, 31 (1944). 
Act of $1945^{9}$ provided that "the Sherman Act . . . shall be applicable to the business of insurance to the extent that such business is not regulated by State law." 10

In passing the McCarran Act, Congress contemplated not only that state legislation must be adequate in scope but also that insurance commissioners must exert effective supervision. This construction of the statute can be gleaned from the language of the statute itself, from its somewhat inconclusive history, ${ }^{11}$ and from congressional awareness of the ineffectiveness and

9. 59 STAT. 33 (1945), 15 U.S.C. $\$ \$ 1011-15$ (Supp. 1946).

10. 59 STAT. 33, 34 (1945), 15 U.S.C. \$ 1013 (Supp. 1946).

11. In support of this construction, see, e.g., Senator Barkley: "If any state, through its legislature, undertakes to go through the form of regulation merely to put insurance companies within that state on an island of safety from Congressional legislation, that effort will be futile." 91 Cong. Rec. 1488 (1945). Attorney General Biddle: "The view we hold toward insurance is not unlike our policy toward railroad rates, that the fixing of rates by private groups without active and definite state approval is a clear contravention not only of the [Sherman] Act but also of the whole theory which underlies the Act, the theory that competition should be free unless it is specifically regulated by the appropriate body. . . . I think there is no doubt at all that insurance rates which are approved by a state are not subject to the Sherman Anti-Trust Act. By that I mean that if a group of insurance companies agreed on rates and filed them with a state commission, and that body took active and definite action, made active and definite approval of those rates, [italics supplied] in that case I think the matter would not be involved at all in the Sherman Act." Quoted by Orfield, Impraving State Regulation of Insurance, 32 MINN. L. REv. 219, 225-6 (1948). President Roosevelt, upon signing Public Law 15: ". . . the anti-trust laws . . . will be applicable in full force and effect to the business of insurance except to the extent that the states have assumed the responsibility, and are effectively performing that responsibility, [italics supplied] for the regulation of whatever aspect of the insurance business may be involved. . . . Congress did not intend to permit private rate fixing, which the anti-trust acts forbid, but was willing to permit actual regulation of rates by affirmative action of the states." White House Release, March 10,1945, quoted in Donovan, Regulation of Insurance Under the McCarran $A c t, 15 \mathrm{LAW} \&$ CONTEMP. Prob. 473, 478 (1950).

After the Act's passage, Senator O'Mahoney said: "It will not be sufficient merely to announce the principle or to pass laws in the several states which formally assert state authority. If there is to be state regulation, the states must have insurance departments which are competent to regulate, that is to say, which are competent to examine, audit, and understand the complexities of the insurance business." Address before the Insurance Federation of New York, December 5, 1945, quoted in Orfield, Improving State Regulation of Insurance, 32 Mins. L. REv. 219, 227 (1948). That construction of the Act is now unequivocally rejected by Senator McCarran, one of the sponsors of the legislation, who asserts that ". . . the intent of the Act was not to accomplish any particular degree of stringency of regulation, but to keep regulation at the State level, and forestall Federal regulation. . . ." Communication to the YALE LAw Journal from Senator McCarran, dated April 21, 1950, in Yale Law Library.

Some light as to the required degree of state supervision can be drawn from the analogous situation presented in Parker v. Brown, 317 U.S. 341 (1943). There, a California statute authorized the establishment of agricultural marketing programs through action of state officials in order to restrict competition for price maintenance purposes. The action by state officials consisted of 1) granting of premiums to institute a program,2) approval and/or modification of the program, and 3) enforcement of the program by statutory sanction. In an action by a producer to enjoin the enforcement of a program, the Supreme 
abuse of state supervision of rate-making prior to the Act. ${ }^{12}$ These deficiencies could be remedied only by federal intervention or by ably enforced state regulation.

The states quickly undertook to follow the congressional invitation and warning. Uniform bills, authorizing rate-making by combinations of insurers and purporting to regulate it, were drafted by the Conference of Insurance Commissioners and representatives of the industry. ${ }^{13}$ The bills

Court upheld its validity despite the price-fixing provision of the Sherman Act on the ground that ". . . the prorate program derives its authority and its efficacy from the legislative command of the state and was not intended to become effective without that command. . . . The Sherman Act gives no hint that it was intended to restrain state action or official action directed by the state." Id. at 350-1. It would appear likely that by analogy to Parker . Brown, the test of validity of rate-fixing legislation should be the degree of actual participation by the state. See Note, State Regulation of the Insurance Business and the Sherman Act, 96 U. or PA. L. REv. 222, 228-9 (1947).

12. The crassest example is that of the state of Missouri. There, in 1922, the Superintendent of Insurance ordered a reduction of $10 \%$ of fire insurance rates. The companies, acting jointly through a rating bureau, promptly raised the rates $162 / 3 \%$. It took 25 years of litigation, hampered by ineffectual state statutes and the bribery of two Insurance Commissioners, to resolve the dispute in the State's favor. See State v. American Insurance Co., 355 Mo. 1053, 200 S.W.2d 1 (1947). In 1943, Attorney-General McKittrick of Missouri, despairing of ever settling the matter, sought the aid of the Justice Department, whose resulting investigation culminated in the South-Eastern indictment, see note 6 supra, which charged 200 companies with combining to maintain arbitrary and non-competitive premium rates. The Congressional hearings, held continuously since October 1943 till the passage of the McCarran Act, were motivated largely by the South-Easlern indictment. Note, State Regulation of Insurance Rating, 41 IL.. L. REv. 647, 648, 654 (1947).

That Congress regarded effective enforcement of a state statute as a prerequisite of antitrust immunity is also inferable from its rejection of the Walter-Bailey-Van Nuys Bill, supra note 7. If Congress was unwilling to place insurance rate making combinations entirely beyond the reach of the antitrust laws, then it is unlikely that Congress intended to acquiesce in the states' circumventing the anti-trust laws by passing deficient statutes or by failing to enforce adequate ones. For legal commentaries supporting this position, see Orfield, Improvement of Insurance Laws, 32 MrNs. L. REv. 219, 224 (1948); Berge, Insurance and the Anti-trust Laws, Proceedings of the Section of INSURANCE Law, AMerican Bar Association 29, 34 (1946); SAwyer, Insurance as INTERstate ComMerce, 78-81 (1945); Dineen, The Rating Problem, Proceedings of the Section of InsurANCE Law, AMERICAN BAR Association 104, 109-10 (1945). But see Naujoks, Regulation of the Insurance Business and Public Law 15, 30 MARQ. L. Rev. 77, 91 (1946), who believes that the McCarran Act is complied with if the state merely sets up a statutory standard for insurance rates.

13. Two model bills were drafted, one to regulate casualty and surety rate-making; the other to apply to the fire, marine, and inland marine fields.

The provisions of the two bills are not materially different. Each attempts to give effect to five main principles: 1) All premiums shall be determined in accordance with written . schedules, based on the analysis of past experience, and open to public inspection. 2) The services of every rating bureau shall be available to every underwriting organization which desires to utilize its services. 3) Every insurer may either file its own rates independently, or adopt those of a licensed rating bureau. 4) The insured shall have access to the schedule by which the premium is determined and the statistics on which the schedule is based. 5) The state insurance commissioner may disapprove any premium schedule filed by any 
were adopted by substantially all the states. ${ }^{14}$ In North Little Rock Transportation Co. v. Casualty Reciprocal Exchange, ${ }^{15}$ they met their first judicial test.

Plaintiff, a taxicab company in Little Rock, Arkansas, incurred excessive liability in the course of his operations. After his automobile liability policy was cancelled on that ground, plaintiff applied for insurance to defendant Aetna Surety Co., a member of defendant National Bureau of Casualty Underwriters. The Bureau did all the rating for Aetna and for more than fifty other insurance companies which subscribed to its services. ${ }^{16} \mathrm{~A}$ premium rate, substantially higher than any plaintiff had previously paid, was established on the basis of the combined experience of the Bureau's subscribers and of data furnished by plaintiff's prior insurer. Any other member of the Bureau would have exacted an identical rate from plaintiff. After paying the first premium, plaintiff brought a treble damages action under the Sherman Act, alleging that defendants' joint rate-making constituted a price-fixing combination which was unlawful despite the McCarran Act and the Arkansas regulatory statute. ${ }^{17}$

The District Court, finding no dispute as to any material facts, ${ }^{18}$ granted defendants' motion for summary judgment. ${ }^{19}$ In a unanimous decision, the Court of Appeals for the Eighth Circuit upheld the lower court, affirming that the bare existence of state regulatory legislation immunized all rate-making activities from the application of the federal antitrust acts. ${ }^{20}$

one if, and only if, he finds that the rates are "excessive, inadequate, or unfairly discriminatory." See Gardner, Insurance and the Anti-trust Laws, 61 HARv. L. REv. 246, 247-9, 260-65 (1948), for a detailed analysis of the provisions of the bills.

The statutes, as adopted by the States, are generally uniform with one exception: some states require affirmative approval of rates by the proper state official within a definite period of time, others provide that if the rates are not disapproved within the waiting period they become effective automatically thereafter. See Note, State Regulation of the Insurance Business, 96 U. of PA. L. Rev. 223, 226-7 (1947). See also page 166 infra.

14. The fire and marine bill is now in effect in all 48 states, Alaska, Hawaii, Puerto Rico and the District of Columbia and the casualty bill in all except Idaho. For a complete listing of state statutes, see Donovan, Regulation of Insurance Under the McCarran Act, 15 LAw \& Contemp. Prob. 471, 485-6 (1950).

15. 181 F.2d 174 (8th Cir. 1950), cert. denied, 19 U.S.L. WeEr 3087 (U. S. Oct. 10, 1950).

16. The member companies of the Bureau write approximately $56 \%$ of all automobile liability insurance written in Arkansas. Transcript of Record, pp. 19, 155-7, 224, North Little Rock Transportation Co. v. Casualty Reciprocal Exchange, 181 F.2d 174 (8th Cir. 1950).

17. ARK. Acts 1947, No. 116, ARK. Stats. ANn. $\$ \$ 66-417-66-431$ (1947). The Insurance Commissioner of Arkansas filed a one-page Intervenor's Brief asserting the validity of the Arkansas statute.

18. Transcript of Record, supra note 16, at 225.

19. North Little Rock Transportation Co. v. Casualty Reciprocal Exchange, 85 F. Supp. 961 (E.D. Ark. 1949).

20. 181 F.2d 174, 176 (8th Cir. 1950).

Plaintiff also contended that the McCarran Act effected an invalid delegation of federal power to the states, and that the Arkansas regulatory act must fall if the federal statute from which the state act derived its force was unconstitutional. But as the Supreme Court had 
Since one of the major objectives of the McCarran Act is to assure that private rate-making will not go unregulated, ${ }^{21}$ the court's decision does not seem justified. Plaintiff should at least have been given the opportunity to demonstrate that Arkansas does not accomplish that purpose.

The Arkansas statute ${ }^{22}$ does not on its face assure effective regulation or show an appreciation of the rationale underlying congressional toleration of combined action in the rate-making field. The statute provides for the filing of all rates, and gives the Insurance Commissioner the power to disapprove those that are "unreasonable, inadequate or discriminatory." But the efficacy of that provision is diminished by the addition of a "deemer clause" which stipulates that rates filed shall be deemed approved unless affirmatively disapproved by the Insurance Department. ${ }^{23}$ While provisions for advance approval of rates would compel the Commissioner to act promptly, deemer clauses relieve him of industry pressure for rate approval and thus encourage administrative lethargy. ${ }^{24}$

previously affirmed the constitutionality of the McCarran Act, Prudential Insurance Co. v. Benjamin, 328 U.S. 408 (1946), the court readily disposed of plaintiff's constitutional arguments.

21. See notes 11, 12 supra.

22. ARK. Acts 1947, No. 116 (1947). In substance, the statute contains the following provisions: § 3: a) Rates shall not be excessive, inadequate or discriminatory. b) In compiling the rates, consideration shall be given to loss experience, a reasonable margin for profit, expenses and all over relevant factors. $\S 4:$ a) All rates must be filed with the Insurance Commissioner. The Commissioner may require the insurer to furnish information in support of the filing. b) A filing shall be deemed to meet the requirements of this act unless disapproved by the Commissioner. $\$$ 5: If the Commissioner finds any filings not to conform to the requirements of the Act, he may suspend them, and, after notice and hearing, disapprove them. $\S 6$ : Rating organizations must be licensed by the Commissioner. As one condition of securing a license, each rating organization must agree to permit non-members to subscribe to its services and to furnish information to members and subscribers without discrimination. This provision was intended to end discrimination against mutual companies. $\$ 7:$ If a member or subscriber of a bureau wishes to deviate from an established rate he may apply to the Commissioner, and permission to deviate shall be granted if the Commissioner after a hearing finds the departure justified. $\$ 9$ : Each rating bureau or individual insurer must upon written request make available to an insured all information pertinent to the promulgation of a rate. A person who feels aggrieved by a particular rate may apply to the Commissioner for a hearing. $\$ 16$ : Violation of the act is a misdemeanor punishable by a fine of between $\$ 50$ and $\$ 500$. The Commissioner may also suspend or revoke the violator's license.

23. ARK. Acts 1947 , No. $166, \S 4$ (d): “. . . A filing shall be deemed to meet the requirements of this act unless disapproved by the Commissioner within the waiting period or any extension thereof."

24. When the uniform bills were enacted, many states felt that they lacked the facilities and experience to act on rates promptly. Where that condition prevailed, recourse was taken to deemer clauses to prevent disruption of the smooth functioning of the insurance industry.

The main objection to deemer clauses is, of course, that they place a premium on inaction and thus detract from the ideal of expeditious, affirmative and effective action on rate filings. Moreover, the feasibility of advance approval of rates has been recognized by many states which incorporated that provision in their model bills, see note 13 supra, and by the 
The statute contains the additional imperfection of permitting groups of insurers to include in the rates filed not only the pooled loss experience of the various companies but also such non-risk elements as administrative expense, acquisition cost, and profit. ${ }^{25}$ As such items are not uniform for all companies, any rate agreed upon by competitors must be so weighted as to protect the least efficient operator. Cost factors such as these, which do not contribute to the goal of actuarial creditability, should not enjoy exemption from the antitrust laws. ${ }^{26}$

Nor are defects in state control statutes the only obstacles to the full regulation envisioned by the McCarran Act. The congressional purpose may also be frustrated by lax enforcement. Thus, while the complexity of rate regulation demands the services of skilled and experienced men aided by adequate appropriations, state insurance departments suffer from a chronic insufficiency of staff and budget. ${ }^{27}$ The Arkansas Department,

fact that advance approval or disapproval has been the practice for years in many states in the field of workmen's compensation insurance. See Dineen, The Rating Problem, ProceEdings of the Section of Insurance LAw, ANerican Bar Association, 105, 107, 110-11 (1945).

Deemer clauses are objectionable on the further ground that they induce reliance on the part of the insurer. Disapproval of a rate subsequent to its effective date and after the agents have been supplied by the companies with manuals works a hardship on the agents. Equal hardship is worked on the companies. Thus, when the State of Virginia ruled that rates filed by certain companies were excessive and ordered the surcharge returned on 4000 policies, the cost of refunding exceeded the total surcharge. Corollarily, the tremendous inconvenience and expense faced by the company in returning a surcharge may dissuade the Commissioner from disapproving a rate even when he eventually finds it to be unreasonable. See Dineen, supra; Note, State Regulation of Insurance Rating, 41 ILL. L. REv. 647, 658 (1947).

25. ARK. Acts 1947, No. $116, \S 3($ a)(1).

26. This position is forcefully maintained by Berge, Insurance and the Anti-Trust Laws, Proceedings of the Section of Insurance Law, American Bar Assoclation 29, 33 (1946).

The opponents of the "pure-premium" theory however insist that that doctrine would destroy whatever advantages are said to derive from the pooling of loss experience. As insurers would be permitted to load the "pure premium" by whatever amount they deemed appropriate, they would be in a position to start the most vicious rate wars by simply making cuts on the expense side rather than on the loss side of the final rate. The familiar pattern of unbridled rate competition would recur. See note 3 supra; Maryott, Why Regulate Insurance Rates? Proceedings of the Section of INsurance LAw, Aurerican Bar AssoCIATION 305, 315-17 (1946).

To this alarmist view, the advocates of "pure-premium" might rejoin that solvency of insurers can be assured by state supervision over capital and investments and that the statutory interdiction of unreasonable, inadequate or discriminatory rates, if properly enforced and applied to "final premiums," would prevent rate wars while retaining substantial leeway for the play of competitive forces. See note 4 supra.

27. If a system of state regulation of rates is to work equitably for both the public and the companies, the men on both sides must be of comparable competence and must have comparable facilities at their disposal. Whether that situation prevails is questionable. While private rating organizations are in general amply staffed with able, experienced and well-compensated individuals, many of whom have devoted a lifetime to some particular 
for example, has at most one trained casualty rater in its employ..$^{28}$

It is therefore open to doubt whether the degree of supervision provided by Arkansas meets the congressional test, since either statutory flaws or inadequate enforcement may negative effective regulation. If, on a trial of the issues, the plaintiff could have shown that the congressional standard was not met, the Sherman Act should have been held applicable. ${ }^{29}$ But the court, by granting defendants' motion for summary judgment upon mere proof of the validity of the legislation, affirmed the irrelevancy of actual

phase of rating, state insurance departments, which until very recently have concerned themselves with rate regulation in comparatively few states, are frequently not adequately staffed to pass on rates. Men who are quite equal to the task of dealing with other phases of insurance regulation may not be equipped to undertake rating. The acquisition of personnel sufficient quantitatively and qualitatively to engage in rating adds such a burden to the Insurance Department budget that in California, for instance, responsible elements opposed the passage of the model bills on the ground that the appropriation would have to be multiplied if the state expected to do a thorough job. And see note 24 supra for the proposition that the existence of a deemer clause in a state regulatory statute may be evidence, in itself, of legislative mistrust in the adequacy of its insurance department.

Insurance Departments may also suffer from lack of integrity on the part of officials, see State v. American Insurance Co., 355 Mo. 1053, 200 S.W.2d 1 (1947) and note 12 supra, or, much more significantly, from high turnover on the part of insurance commissioners and the consequent breaks in the continuity of departmental policies. See Dineen, The Rating Problem, Proceedings of the Section of Insurance Law, American Bar Association 104, 105-6 (1945).

28. The Arkansas Insurance Department is headed by a Commissioner who receives a yearly salary of $\$ 5,000$. A staff of 12 full-time employees contains one trained fire rate analyst, a casualty "supervisor" as well as some clerical help. The yearly budget of the Department is $\$ 64,064$. See ARK. Acts 1937 , No. $2, \S 3$. In the automobile liability field alone, the yearly underwriting, supervised by the Department involves $\$ 4,332,690$. Transcript of Record, p. 158, North Little Rock Transportation Co. v. Casualty Reciprocal Exchange, 181 F.2d 174 (8th Cir. 1950). The Assistant Insurance Commissioner of Arkansas has indicated that if the Department had a larger staff and/or budget, it could do a more thorough job of inquiring into the fairness of rates filed. Communication to the YALE LAW JouRNaL from Whit Morgan, Assistant Insurance Commissioner of Arkansas, dated April 12, 1950 in Yale Law Library.

29. Cf. the applicability of the antitrust laws to railroad rates. In Georgia v. Pennsylvania Railroad Co., 324 U.S. 439 (1945), the Supreme Court upheld a Sherman Act complaint charging some 20 railroad companies with engaging in a rate-fixing conspiracy against the railroads' contention that the Sherman Act was inapplicable because the railroad rates were subject to ICC regulation. As the Commission's power to reject rates was limited to those that are unjust, unreasonable or discriminatory, the Court felt that Sherman Act protection should extend to rates fixed collusively though they are within the "zone of reasonableness." Id. at 461. See Dumbauld, Rate-fixing Conspiracies in Regulated Industries, 95 U. of PA. L. REv. 643 (1945) passim. If the anti-trust laws apply where administrative supervision does not by law extend to every cranny of a regulated industry, they should apply where that supervision is ineffectual. Moreover, there is greater assurance in the railroad than in the insurance industry that rates as originally fixed will be fair because of the existence in the railroad industry of well-established forums in which sellers and buyers (carriers and shippers) get together to discuss proposed rate changes before they are filed See Dineen, The Rating Problem, Proceedings of the Section of Insurance Law, AuserICAN BAR Association 105, 108 (1945). 